\section{Archaeological chert artifacts from Atapuerca sites (Burgos, Spain): characterization, causes of decay and selection of compatible consolidating products}

\section{Artefatos arqueológicos de cherte de Atapuerca (Burgos, Espanha): caracterização, causas de deterioração e seleção de produtos de consolidação compatíveis}

\author{
AINARA \\ ZORNOZA-INDART $^{1 *}$ \\ PAULA LOPEZ-ARCE ${ }^{2,3}$ \\ LUCÍA LÓPEZ-POLÍN ${ }^{4}$ \\ 1. Department of Painting, \\ Faculty of Fine Arts, University \\ of the of the Basque Country \\ (UPV/EHU), Lejona, Spain \\ 2. University College \\ London (UCL), Institute for \\ Environmental Design and \\ Engineering (IEDE), The \\ Bartlett, School of Environment, \\ Energy and Resources, Faculty of \\ the Built Environment, London, \\ United Kingdom \\ 3. Property Care Association, \\ Cambridgeshire, United \\ Kingdom \\ 4. Institut Català de \\ Paleoecologia Humana i \\ Evolució Social (IPHES), Zona \\ Educacional, Tarragona, Spain \\ *ainara.zornoza@ehu.eus
}

\section{KEYWORDS}

Archaeological chert artifacts

Consolidation Nanosilica Nanolime Acrylic resin Ethyl silicate

\section{PALAVRAS-CHAVE}

Artefatos arqueológicos de cherte

Consolidação

Nanossílica

Nanopartículas de $\mathrm{Ca}(\mathrm{OH})_{2}$ Resina acrílica Silicato de etilo estavam mais alteradas e pulverulentas, exigindo consolidação. Neste estudo foi avaliada a eficácia dos produtos de consolidação tradicionalmente usados pelos conservadores (resina acrílica e silicato de etila) para preservar os restos de cherte, juntamente com novos produtos baseados em nanopartículas $\left(\mathrm{SiO}_{2}\right.$ e uma mistura de nanopartículas de $\mathrm{SiO}_{2}$ e $\left.\mathrm{Ca}(\mathrm{OH})_{2}\right)$. As alterações produzidas por estes produtos consolidantes nas propriedades físicas (morfologia e coesão da superfície) e estéticas foram avaliadas por técnicas não destrutivas (teste de descamação, espectrofotometria e rugosidade da superfície óptica), e destrutivas, como SEM e DRX. 


\section{Introduction}

Chert is a sedimentary cryptocrystalline siliceous rock primarily composed of quartz $\left(\mathrm{SiO}_{2}\right)$ and other silicate minerals like moganite, opal, or clay or carbonates and organic material, which are considered impurities [1]. The intrinsic properties of chert, such as hardness and conchoidal fracture, had made it widely used as a raw material for knapping throughout the history of mankind. Although it is a durable material, chert artifacts are often found in poor conservation conditions in archaeological sites such as Sierra de Atapuerca, limiting their study and requiring consolidation treatments to enable examination and conservation. Sierra de Atapuerca (Burgos, Spain) is a limestone karst complex with many cavities in which archaeological fieldwork has been systematically carried out since 1978 [2]. The archaeological site has provided crucial data on human evolution in Eurasia from 1.2 Myr to the end of the Middle Pleistocene [4]. Therefore, it was included in the UNESCO's World Heritage list in 2000. Fieldwork extended throughout the cave system and around the range, including open-air and rock shelter sites, has increased the time period up to Holocene occupations [6].

The chert samples included in this study come from Gran
Dolina and Galería (Figure 1a), two of the cave sites located in the Trinchera del Ferrocarril. The stone tools recorded at Galería and Gran Dolina Caves comprise various raw materials such as sandstone, quartzite, and other less wellrepresented materials, but the majority are chert artifacts, particularly Neogene chert that is usually highly altered. It is formed after silica precipitation in a hypersaline environment rich in gypsum and carbonates. It appears in the Neogene border of the Duero River and belongs to the late Miocene [10]. Almost all the Neogene chert artifacts from the Atapuerca sites have been whitened and lost their original luster. They also present visibly increased surface porosity, with an aspect that corresponds to the commonly described "white patina" [11]. The alteration, however, does not concentrate on the surface; in fact, it is more pronounced in the inner part, where usually the chert becomes powder [14]. In some cases, this issue impedes the recovery of intact artifacts from the site, as they often break during the excavation works and, on many occasions, require consolidation before being lifted or subsequently handled (Figure $1 b-d$ ).

Up to now, the chert artifacts of the Atapuerca sites have predominantly been consolidated with the acrylic resin Paraloid B72 and, occasionally, with ethyl silicate-based products [14].

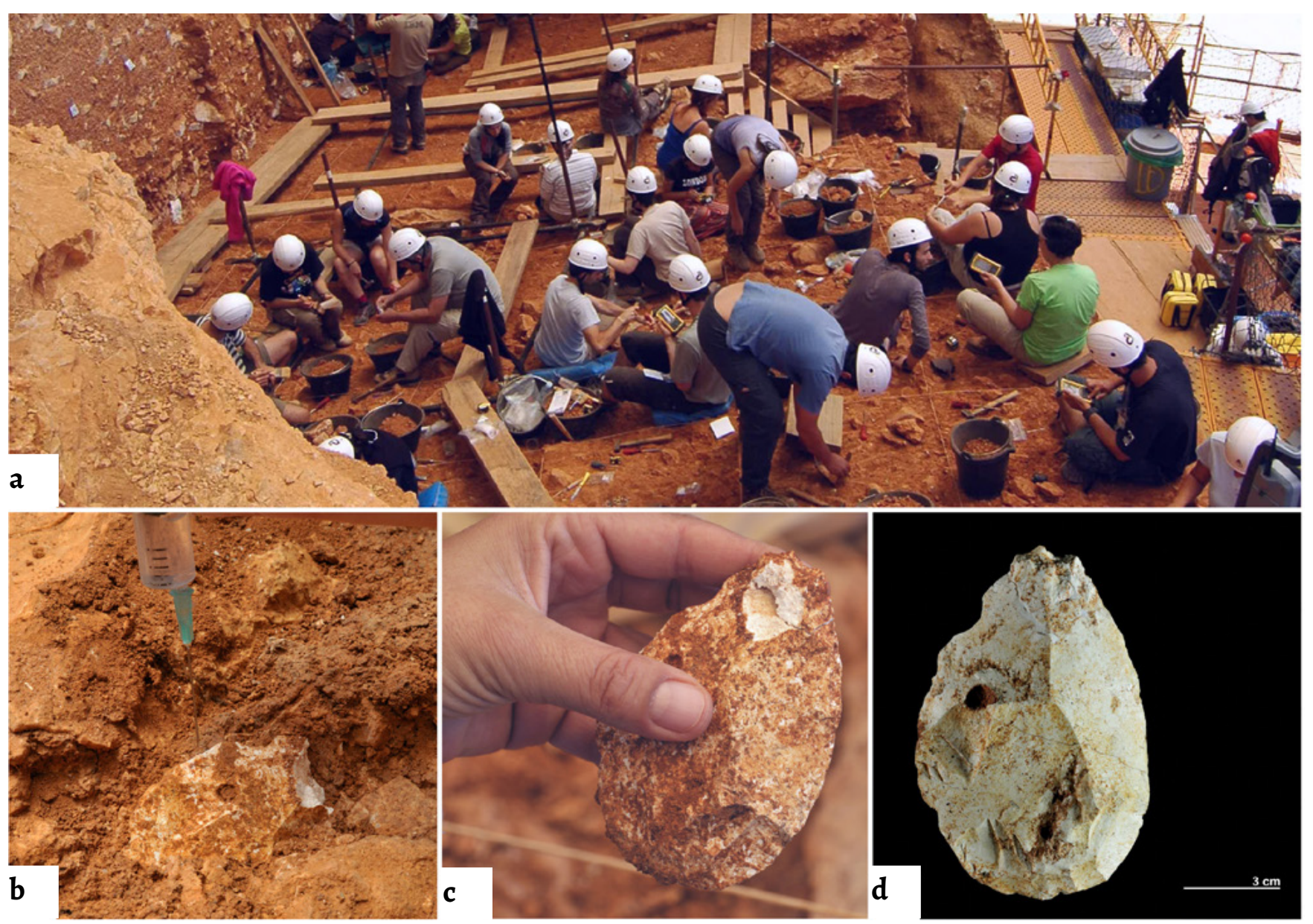

Figure 1. Chert samples collected from Sierra de Atapuerca (Burgos, Spain) archaeological site: $a$ ) Upper part of Gran Dolina site; $b$ ) Prior consolidation with acrylic resin Paraloid B72 of an altered chert artifact found in the TD10.2 unit; $c$ ) Lifting of the treated artifact; $d$ ) Chert stone tool after conservation treatments. 
The aim of this research is to characterize chert samples collected from the archaeological Atapuerca site to determine their composition, texture and conservation state, as well as the causes of their decay in order to select the most compatible consolidation treatments. In addition, we assessed the efficacy of the most widely-used consolidation treatments by comparing changes on the aesthetic and physical properties of the treated substrates with those produced by two novel consolidation products based on $\mathrm{SiO}_{2}$ and $\mathrm{Ca}(\mathrm{OH})_{2}$ nanoparticles. These products are still not widely used by conservators for conservation purposes and unreported for archaeological prehistoric stone tool preservation thus far.

\section{Materials and methods}

\section{Chert samples}

In the Atapuerca archaeological site, the chert is divided into two petrological groups based on its origin and geological period of formation, i.e., Cretaceous and Neogene $[10,16]$. Neogene chert comes from Late Miocene formations and is found as large blocks outcropping in marls and marly limestone, and was formed due to silica precipitation in a hypersaline environment rich in gypsum and carbonates [10]. Previous studies have determined that this type of chert is composed of quartz and moganite; it also contains a certain amount of gypsum, calcite (filling some pores), and occasional impurities. Microscopically it appears highly heterogeneous and particularly porous in crystalline zones [17].

Six chert samples classified as having different degrees of decay based on visual inspection were selected to determine
Table 1. Studied chert samples from Atapuerca archaeological site.

\begin{tabular}{|c|c|c|c|c|c|}
\hline \multirow{2}{*}{ Nomenclature } & & \multicolumn{4}{|c|}{ Nomenclature on site } \\
\hline & & Year & Level & Square & $\mathrm{N}^{\circ}$ \\
\hline \multirow{4}{*}{$\begin{array}{l}\text { Middle Pleistocene } \\
\text { lithic remains }\end{array}$} & $\mathrm{SX}_{1}$ & 2008 & TD1o & M18 & 341 \\
\hline & $\mathrm{SX}_{3}$ & 2004 & GIII & No3 & 71 \\
\hline & SX9 & 2004 & GIII & $\mathrm{No} 3$ & 70 \\
\hline & SX17. & 2011 & TD1o & L13. & 66 \\
\hline \multirow{2}{*}{$\begin{array}{l}\text { Fresh chert samples } \\
\text { collected from the } \\
\text { surrounding outcrops }\end{array}$} & SX18 & & & & \\
\hline & SX19 & & & & \\
\hline
\end{tabular}

their composition, texture and state of conservation (Table 1). The causes of their decay were also studied with the purpose of being able to select and evaluate the necessary conservation treatments and the most suitable consolidating products for preserving the samples. Four samples of chert lithic remains came from the Middle Pleistocene units of the site. Two of them (samples SX3 and SX9) were collected from unit GIII of Galería site, dated at around $300 \mathrm{ky}$ [18] and another two (samples SX1 and SX17) were collected from the TD10.2 unit in the upper part of Gran Dolina and dated at around $400 \mathrm{ky}[10,20]$. Two further, fresh chert samples, were collected from the surrounding outcrops in the Sierra de Atapuerca (samples SX18 and SX19) with the aim of comparing these with the decayed samples collected from the archaeological sites (Figure 2). The soil remains that covered the samples from the dig were carefully removed from their surfaces with a brush, in order to carry out the compositional and textural analyses of the clean cherts.

\section{Study of consolidation treatments}

Sixteen chert samples from Middle Pleistocene units were
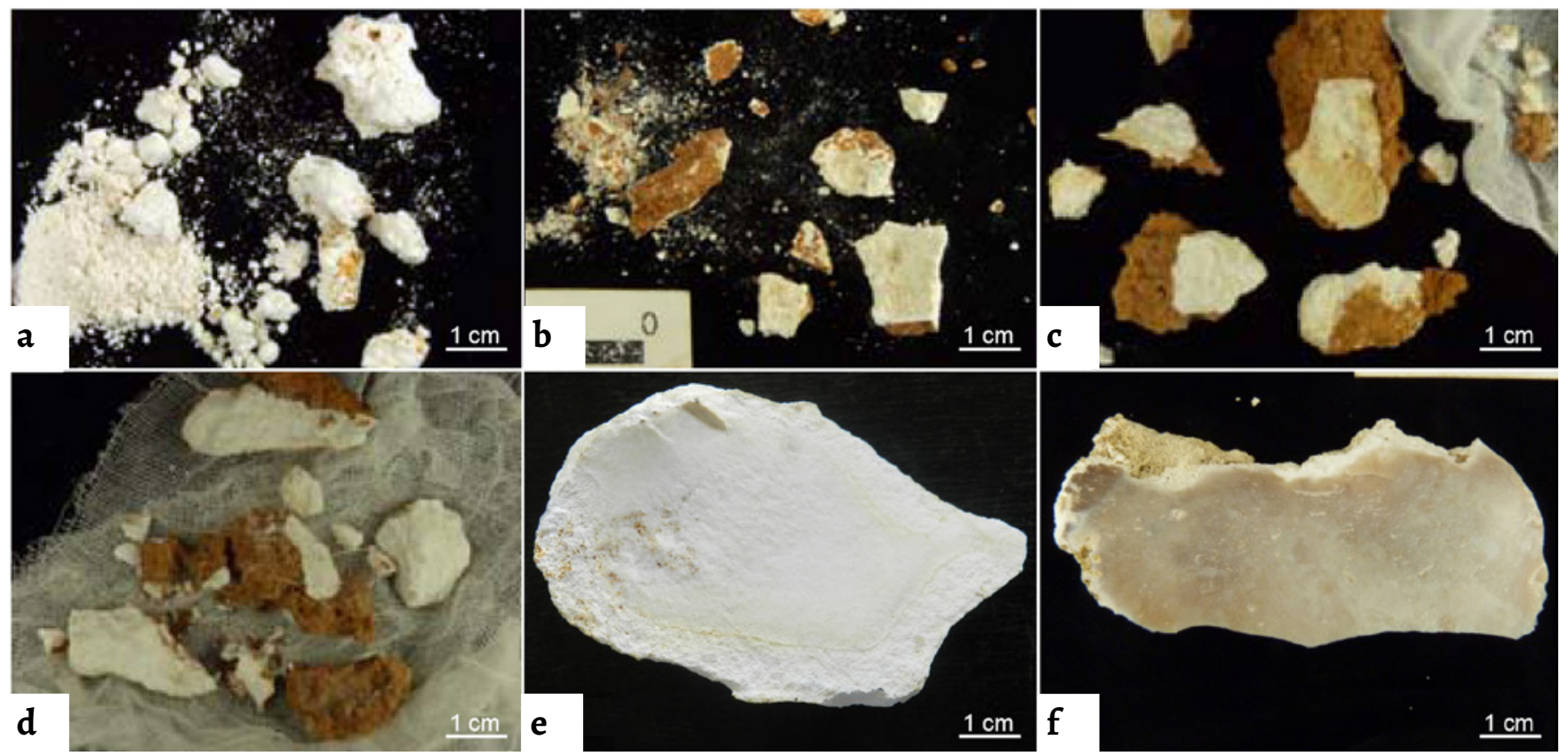

Figure 2. Studied chert samples: a) Sample SX17; b) Sample SX9; c) Sample SX3; d) Sample SX1, from the archaeological site of Atapuerca; e) Sample SX19, and f) Sample SX18 from the surrounding outcrops. 
collected in two different sites to evaluate the different consolidating products after their treatment. Six samples were selected from the TD10.2 unit in the upper part of Gran Dolina and ten samples were collected from unit GIII at the Galería site. The samples were large enough to be analyzed using various analytical techniques and test methods (Table 2). The 16 selected samples (four control samples and 12 samples to be treated, three samples for each consolidating product) initially displayed a similar degradation state, i.e. milky white in color, loss of density and mass, superficial decohesion, large roughness, friable surface and loss of external areas (apart from samples SX2 and SX8 which preserved some parts of the most superficial area). As explained above, the soil covering the samples was brushed off to enable their characterization and further application of the consolidating products.

As it was described in a previous work by ZornozaIndart et al. [21], four types of consolidating products were applied to consolidate chert artifacts (Table 2). The first one comprises the most widely-used conventional alkoxysilane consolidant (ethyl silicate: Tegovakon V100, Evonik Industries AG). This product was chosen because it is highly compatible with siliceous substrates and can form chemical bonds with substrates containing hydroxyl groups during the sol-gel process [22]. The second product was a colloidal dispersion of silica nanoparticles in water (Nano Estel, C.T.S.) with a particle size of $10-20 \mathrm{~nm}$ and a concentration of $150 \mathrm{~g} / \mathrm{L}$. This product was chosen because it is a novel product and is also expected to be chemically compatible with siliceous substrates due to the formation of a silica gel with silanol groups [23].

The third product was an acrylic resin, the most widelyused by conservators (Paraloid B72 by Dow Chemical), in a concentration of $5 \%$ in xylene. The choice of solvent is based on its volatility. When Paraloid is used as a consolidant, a low volatile solvent is used to allow maximum penetration of the product (conservators use to apply acetone as a solvent when the product is used as an adhesive because the rapid evaporation rate of the acetone decreases the penetration of the product in the porous network remaining only on the surface). Although Paraloid is the most used consolidant, silicate-based products with a lesser penetration depth than ethyl has been reported [24].

Finally, a mixture of two inorganic products based on colloidal dispersions of nanoparticles was used (the aforementioned Nano Estel, and Nanorestore C.T.S., i.e. $\mathrm{Ca}(\mathrm{OH})_{2}$ colloidal dispersion in isopropyl alcohol with a particle size of $\leq 100 \mathrm{~nm}$ and a concentration of $5 \mathrm{~g} / \mathrm{L}$ ), in a ratio of 1:1.

The products were applied to reproduce the application method used nowadays by most restorers, which usually follow the recommendations stated by the manufacturers. The application was performed through a capillary tube and deposited drop-by-drop (the most frequently used application method in conservation of archaeological artifacts) onto the surface of the samples. Then, the samples were exposed to a humid environment $\left(19 \pm 1^{\circ} \mathrm{C}\right.$ temperature (T) and $93 \pm 3 \%$ relative humidity $(\mathrm{RH})$ ) for one month, even though it should be noted that the time suggested by the manufacturer (2-4 weeks) might not be time enough to complete the polymerization process. This high $\mathrm{RH}$ was selected because the carbonation rate of $\mathrm{Ca}(\mathrm{OH})_{2}$ nanoparticles is faster under higher RH [25]. In addition, new silica nanoparticles can be used in conditions where ethyl silicate or acrylic resin are not appropriate, such as in the presence of high levels of humidity, free water or wet

Table 2. Chert samples and applied consolidating products by dripping.

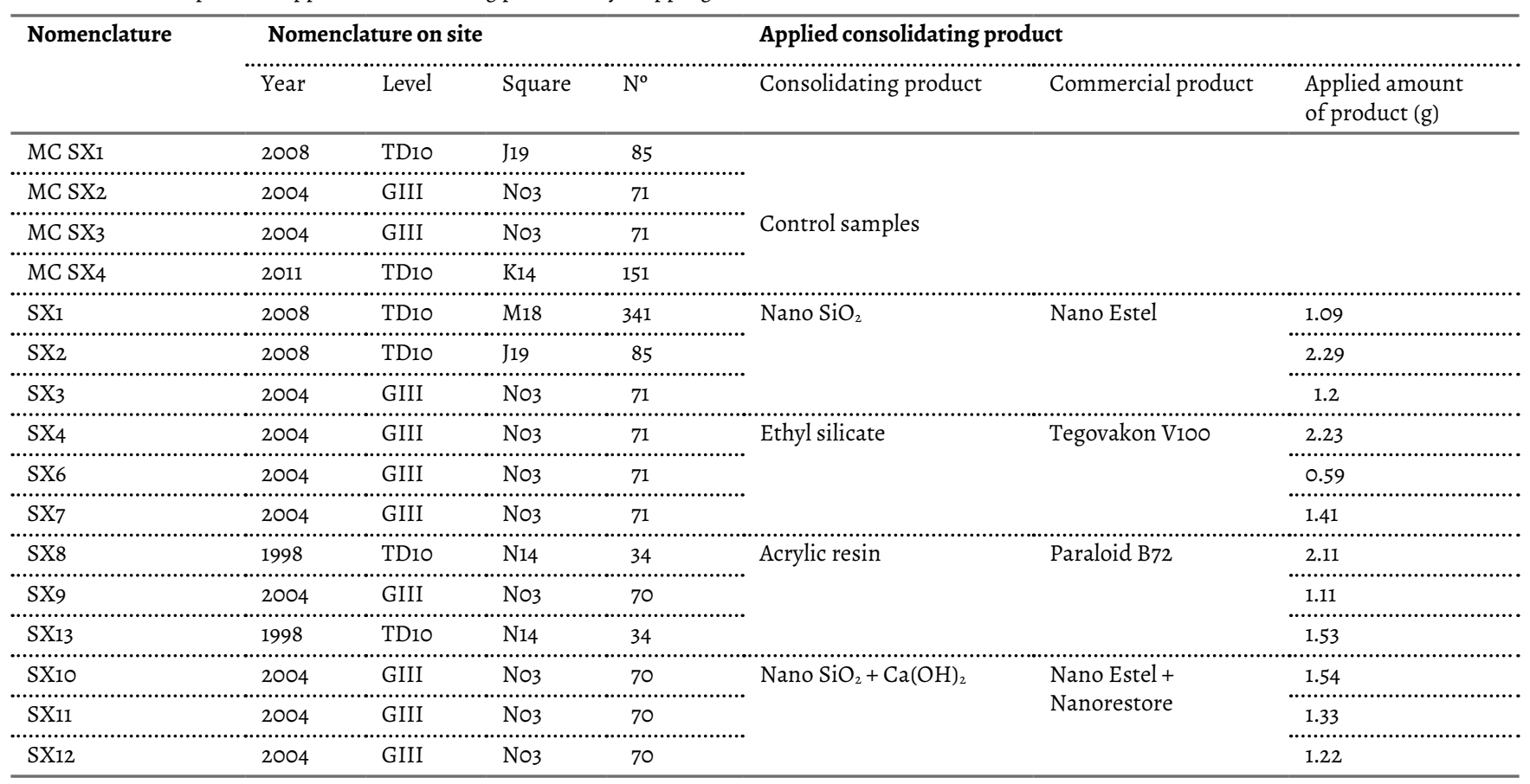


surfaces. Note that moisture is common in archaeological excavated objects, which can generate compatibility problems with conservation products. The temporary hydrophobicity of ethyl silicates, already investigated by other authors, can preclude future treatments, as the consolidation treatment is usually followed by cleaning of the samples. In this deeper cleaning procedure, hydric solvents are used, but, the cleaning is not possible if there is a hydrophobic layer. In addition, if a volumetric reintegration is made and the surface is hydrophobic, the adhesion of the reintegration stuccos is hinder. Also, the hydrophobicity of some consolidants preclude desalination treatments (very common in buried archaeological pieces). Although the concept of reversibility has been widely studied and discussed, the concept of retreatability is less studied. Research is usually focused on the application of these treatments, especially consolidation products to freshly excavated or deteriorated materials but not to samples that have been already treated with other products. Therefore and despite being one of the most important criteria in the selection of conservation products and treatments, retreatability is less considered in conservation studies.

The time of this hydrophobic behavior varies according to the authors and the research, as well as with commercial products applied and substrates treated. The hydrophobicity has been observed until 28 days of curing [26], five weeks [27], three weeks [28], one month [29], two months [30] and several months $[22,31]$.

Environmental data loggers, ibuttons model DS1923-F5, were introduced into the container and also placed in the laboratory to register $\mathrm{T}$ and $\mathrm{RH}$ during the test, using the software OneWireViewer version 3.04. Further details on the use of these consolidating products, application method and environmental conditions are described in ZornozaIndart et al. [21].

\section{Analytical techniques and test methods Chert characterization}

The decay and conservation state of the samples was studied following the protocol and terms established by Font et al. [15] based on macro-visual inspection with the naked eye. In addition, X-ray diffraction (XRD) was used to determine the main mineralogical phases and degree of crystallinity of the samples. A Phillips PW-1710 diffractometer was used with $\mathrm{CuK} \alpha$ radiation to study the total powder fraction of samples. The measurements were conducted by step scanning $2 \theta$ from $2^{\circ}$ and $68^{\circ}$, scan step size $0.02^{\circ}$, scanning rate $2 \% \mathrm{~min}$, with a continuous mode and beam intensity of $40 \mathrm{kV}$ and $40 \mathrm{~mA}$. Three chert samples (SX3, SX17 and SX18) were analyzed with higher precision to distinguish the different silica polymorphs by means of a multi-purpose PANalytical X'Pert MPD with $\mathrm{CuK \alpha}$ radiation. Analysis conditions were $2 \theta$ between $2^{\circ}$ and $90^{\circ}$, scan step size $0.02^{\circ}$, count time of 3 seconds per step, with continuous mode and beam intensity of $45 \mathrm{kV}$ and $40 \mathrm{~mA}$. Furthermore, sample
SX18 was preserved and analyzed, without grinding, using micro-diffraction analyses to obtain several diffractogram patterns on various spots of interest. The mineralogical phases were identified by comparing the sample with the Joint Committee on Powder Diffraction (JCPDS) database and Bruker AXS DiffracPlus EVA software.

Ion chromatography (IC) analyses were performed to identify soluble salts in all the samples, i.e. type and quantity of some anions $\left(\mathrm{Cl}^{-}, \mathrm{NO}_{3}{ }^{-}\right.$and $\left.\mathrm{SO}_{4}{ }^{2-}\right)$. Soil samples collected from the same dig areas as the chert samples were also analyzed to ascertain whether or not the presence of salts. Approximately $0.1 \mathrm{~g}$ of sample was dissolved in $10 \mathrm{ml}$ of Milli-Qultrapure water and placed for $45 \mathrm{~min}$ in an ultrasonic bath at room temperature. Afterward it was centrifuged for $5 \mathrm{~min}$ at $3500 \mathrm{rpm}$ and $3400 \mathrm{rfc}$ centrifugal force. The soluble salts in the extracted sample were quantified using a Metrohm 761 Compact IC ion chromatograph.

The surface morphology and texture of the specimens were examined by means of environmental electron scanning microscopy (ESEM) using an Inspect FEI microscope coupled with energy dispersive X-ray spectroscopy (EDS) (model 7509 Oxford Instrument Analytical, UK).

Optical surface roughness (OSR) analyses were also performed on the surface of samples SX18 and SX19 (the other samples were too small to take these measurements on). This was carried out to evaluate changes in the surface roughness caused by decay processes. The equipment used was a contact-free surface profilometer (white light), TRACEiT, Innowep GmbH. The OSR analyses included the generation of 3D-topography maps $\left(25 \mathrm{~mm}^{2}\right)$ using Gyddion 2.44 software displaying the average roughness parameters according to ISO 4287 (1998) standards [33], i.e., Ra (arithmetic mean of the absolute values of profile deviations from the mean line) and $\mathrm{Rz}$ (sum of the vertical distances between the five highest peaks and the five deepest valleys within the sampling length). The cutoff $(\lambda c)$ used for the calculations was $0.80 \mathrm{~mm}$.

\section{Consolidation}

The sixteen specimens were also analyzed using various non-destructive techniques and test methods both before application of the consolidating products and one month later.

The surface morphology, texture of the specimens, and the distribution and morphology of consolidating products was examined by ESEM-EDS.

A peeling test was carried out on the surface of the samples to assess the detachment degree of the material using transparent double-sided adhesion tape (Tesa), with $1.5 \mathrm{~cm}$ wide $\times 5 \mathrm{~cm}$ long, on 1 zone per sample (ten sequences) and 90 seconds per each sequence. This method is commonly used for evaluating the consolidation effect of the products on stone surfaces by determining the detached material after applying and removing pressure sensitive tape over the surface [34]. 
Spectrophotometry was performed to determine the color parameters, with a spectrophotometer MINOLTA CM-70od using the CieLab color space; the measuring area was 1-3 mm. Three measurements were conducted for each sample, the standard illuminant was D65 and the observer angle, $10^{\circ}$. The measured parameters were $L^{*}$, which accounts for luminosity, $\mathrm{a}^{*}$ and $\mathrm{b}^{*}$ coordinates ( $\mathrm{a}^{*}$ being the red-green parameter and $b^{*}$ the blue-yellow), total chrome difference $\Delta \mathrm{C}^{*}$ (from the formula $\left.\Delta \mathrm{C}^{*}=\left(\Delta \mathrm{a}^{*}\right)^{2}+\left(\Delta \mathrm{b}^{*}\right)^{2}\right)^{1 / 2}$ ), and total color difference $\Delta \mathrm{E}^{*}$ (from the formula $\Delta \mathrm{E}^{*}=\left(\left(\Delta \mathrm{L}^{*}\right)^{2}+\left(\Delta \mathrm{a}^{*}\right)^{2}\right.$ $\left.\left.+\left(\Delta \mathrm{b}^{*}\right)^{2}\right)^{1 / 2}\right)$. The white (WI) and yellow (YI) indices were measured according to ASTM E313-73 [35] and brightness was measured according to ISO 2470-2 [36].

\section{Results and discussion}

\section{Characterization of chert samples Macroscopic examination}

The main results from the macroscopic examination are shown in Table 3. All the weathered samples from the archeological sites displayed a milky-white color and lost the characteristic densely packed cohesion of chert. No fissures or fractures were observed with the naked eye in any of the samples. However, all of them showed a coarse surface with different degrees of decohesion (Figure $2 a-d$ ). Sample SX17 (Figure $2 a$ ) was the most damaged chert. Part of this sample was broken down into a white powder and the rest was very dusty, friable and disaggregated on the surface. Sample SX9 (Figure 2b) displayed a certain degree of compacted structure, slightly higher than the previous sample. It also had a dusty, friable and disaggregated surface that powdered to the touch. In spite of some lost material, samples $\mathrm{SX}_{3}$ and SX1 (Figure $2 c-d$ ) seemed to be better preserved compared to the other samples. These were more compacted and did not present the same degree of disaggregation as the

Table 3. Macroscopic examination of archaeological chert samples.

\begin{tabular}{|c|c|c|}
\hline \multicolumn{2}{|l|}{ Nomenclature } & \multirow{3}{*}{$\begin{array}{l}\text { Macroscopic examination } \\
\text { Better preserved. More compacted, without } \\
\text { disaggregation but with coarse, grainy and } \\
\text { quite dusty surfaces. }\end{array}$} \\
\hline \multirow{4}{*}{$\begin{array}{l}\text { Middle } \\
\text { Pleistocene } \\
\text { lithic } \\
\text { remains }\end{array}$} & $\mathrm{SX}_{1}$ & \\
\hline & $\mathrm{SX}_{3}$ & \\
\hline & SX9 & $\begin{array}{l}\text { Certain degree of compacted structure but, } \\
\text { dusty, friable and disaggregated surface } \\
\text { that powdered to the touch. }\end{array}$ \\
\hline & SX17 & $\begin{array}{l}\text { Most damaged. Broken down into a } \\
\text { white powder, very dusty, friable and } \\
\text { disaggregated on the surface. }\end{array}$ \\
\hline \multirow[b]{2}{*}{$\begin{array}{l}\text { Fresh chert } \\
\text { samples }\end{array}$} & SX18 & $\begin{array}{l}\text { Grayish-brown in color with some faceted } \\
\text { core areas that were fine grained and } \\
\text { crystalline. }\end{array}$ \\
\hline & SX19 & $\begin{array}{l}\text { Muddy-white in color with a coarse but } \\
\text { compacted surface. Two different zones: a } \\
\text { more crystalline, compacted and smoother } \\
\text { core zone, and another whiter, coarser and } \\
\text { dustier external zone that appeared more } \\
\text { weathered. }\end{array}$ \\
\hline
\end{tabular}

previous samples, even though they also had coarse, grainy and quite dusty surfaces. Among the chert samples from the outcrops surrounding the archaeological sites, sample SX19 (Figure 2a) was muddy-white in color with a coarse but compacted surface, similar to samples SX1 and $\mathrm{SX}_{3}$. Two different zones could be distinguished on the surface of this sample, a more crystalline, compacted and smoother core zone, and another whiter, coarser and dustier external zone that appeared more weathered. Sample SX18, also from the surrounding outcrops, was grayish-brown in color with some faceted core areas that were fine grained and crystalline (Figure 2f). Only this latter zone of this particular sample displayed the characteristic cutting edge morphology caused by the distinctive conchoidal fracture of the chert. This core zone was surrounded by a $1 \mathrm{~mm}$-thick crust, grayish-white in color and earthy but with a compacted appearance. This was circled by another $5 \mathrm{~mm}$-thick, white external crust that in spite of its compacted structure displayed a similar aspect to the more weathered samples previously described (milky-white in color, rough, dusty and with a disaggregated surface).

\section{$\mathrm{X}$-ray diffraction (XRD)}

All the XRD results obtained from the total powder samples showed the presence of quartz $\left(\mathrm{SiO}_{2}\right)$ and moganite $\left(\mathrm{SiO}_{2}\right.$ polymorph), with the exception of $\mathrm{SX}_{9}$ and $\mathrm{SX}_{17}$ which were solely composed of quartz and calcite $\left(\mathrm{CaCO}_{3}\right)$; SX17 had a large amount of calcite. These results are in agreement with those obtained by other authors for similar materials $[17,37]$. Sample SX19 had more moganite in the whiter external zone compared to the more crystalline core zone. The amount of moganite was even higher in sample $\mathrm{SX}_{3}$, which also displayed some calcite, followed by sample SX18 (Figure $3 a$ ). The four diffractogram patterns obtained in different spots on this unground sample indicate certain mineralogical differences (Figure $3 b$ ). The external zone (surrounding crust; crust 1) was mainly composed of quartz and calcite with a lower proportion of dolomite, and had poorly-defined broad peaks indicating less crystallinity. The most external white crust (crust 2) showed only quartz and very well-defined moganite peaks. The quartz peak at $41^{\circ}$ $2 \theta$ only appeared well-defined in the crystalline core zones of the sample (Chert 1; Figure 3b). As inside the same nodule or quartz level textures and impurities can change, that's the main difference between the faceted and colored areas in the crystalline core zone of the sample [38]. This is also the main difference between the faceted and colored areas in the crystalline core zone of this sample, since changes in texture and impurities can occur inside the same nodule or quartz level [38].

The chert samples from the archaeological site and the most weathered samples from the surrounding outcrops (with a totally disaggregated surface), i.e., samples SX17, SX9 and the most external crust of sample SX18, displayed quartz and calcite minerals. The less-weathered samples, 

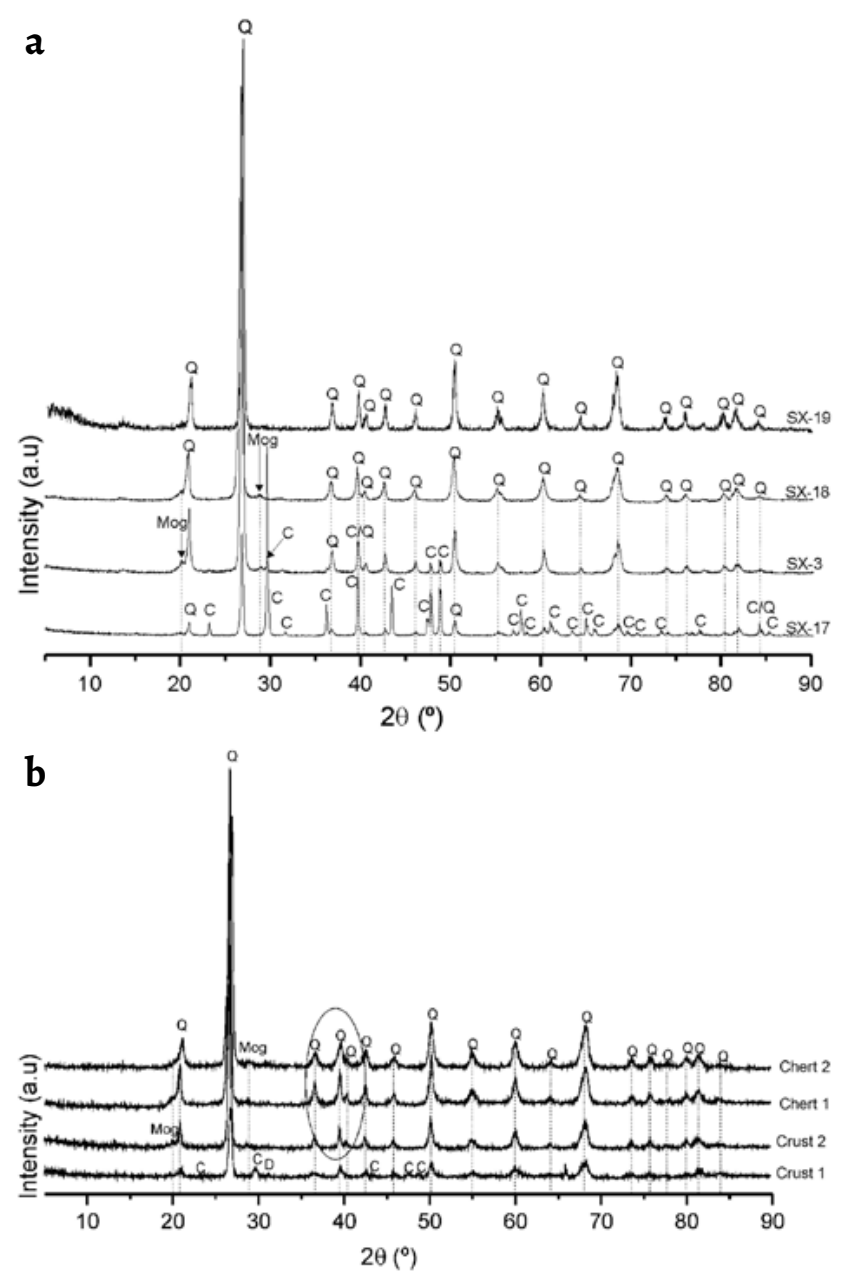

Figure 3. X-ray diffraction (XRD) patterns of the archaeological chert samples: a) XRD obtained from the total powder samples; $b$ ) Diffractograms from micro XRD analysis (no powdered samples) obtained in SX18 sample, in the external (crust) and in the core zones (chert). Q: quartz; Mog: moganite; C: calcite; D: dolomite.

with coarse, grainy but more compacted surfaces (samples $\mathrm{SX}_{1}, \mathrm{SX}_{3}, \mathrm{SX}_{19}$ and middle crust of sample SX18), contained quartz, moganite and small amounts of calcite. Finally, the best preserved crystalline cores of samples SX18 and SX19 had only quartz.

High alkalinity, sulfates and ferric ion activity play a certain role in the precipitation of moganite [38]. In the research work on Mogan rocks from Gran Canaria, Spain, carried out by García-Guinea et al. [39], it was found that their core area and edges (more porous, whiter and with additional ions) resulted in a different cathodoluminescence spectrum. This was interpreted as late hydrothermal weathering mechanisms with alkaline ions, metals and volatiles to form moganite. In silica weathering, moganite represents an intermediate position between opaline phases and quartz [38]. It is considered a metastable phase which can be transformed into quartz if there is enough time or there are changes in the surrounding environmental conditions [40]. The abundance of moganite in arid environments has been partially explained by the lack of water for mediating the dissolution of this mineral and the simultaneous precipitation of quartz, as between $10 \%$ and $80 \%$ of the silica present in different varieties of fine-grained quartz is in fact moganite [41]. In this case, the quantity of moganite is a key indicator in the decay of chert samples. The crystalline core zone of sample SX18 from the outcrops, which only has quartz, is in a good state of preservation. The chert samples from the archeological site and the outer crust of sample SX18 (with mixtures of quartz-moganite) are weathered, with coarse, porous and disaggregated surfaces. In quartzmoganite mixtures, fast weathering may occur, as moganite is more soluble than quartz. This means that those parts of the chert containing moganite could be more weathered and more porous, favoring fluid penetration leading to disaggregation processes. In the research conducted by Navazo et al. [17], poorly-preserved Neogene chert, and massive, well-preserved Cretaceous chert samples with low porosity, both from outcrops close to the Atapuerca mountain range, were compared. They also found that moganite played a significant role in chert decay and preservation state, since the quantity of this mineral was the main difference between the two types of chert. Increased amounts of calcite and decreased moganite in the samples, relating to a greater degree of decay and weathering, may be due to the fact that the areas originally comprising moganite could have been weathered or dissolved. This favors fluid penetration and pore filling by external compounds [39], in this case by calcite since these cherts were within limestones rock settlements.

The absence of moganite in the most weathered chert samples could be in line with the data provided by Heaney \& Post [41] and Rodgers \& Cressey [40], who report that moganite does not appear in weathered or eroded cherts, since it completely disappears due to dissolution processes.

\section{Ion chromatography (IC)}

Ion chromatography data indicate negligible amounts of soluble salts (chlorides, nitrates and sulfates), with total weight percentages of salts below $0.08 \%$ in all samples as it was described in Zornoza-Indart et al. [21]. The soil samples collected from the same dig areas where the chert samples were buried also contain insignificant amounts of salts. Therefore, the decay of the chert samples by salt crystallization processes is discounted.

\section{Optical surface roughness (OSR)}

The surface roughness analysis results are shown in Table 4.

Table 4. Optical surface roughness (OSR) parameters (Ra and Rz) of fresh chert samples SX18 and SX19, measured on the external crust, weathered surfaces and smooth areas.

\begin{tabular}{|c|c|c|c|}
\hline Sample & Area & $\mathbf{R a}(\mu \mathrm{m})$ & $\mathrm{Rz}(\mu \mathrm{m})$ \\
\hline \multirow[t]{2}{*}{ SX18 } & Smooth & $2.57 \pm 0.40$ & $9.35 \pm 1.37$ \\
\hline & Crust & $7.43 \pm 0.34$ & $40.82 \pm 1.84$ \\
\hline \multirow[t]{2}{*}{ SX19 } & Smooth & $3.67 \pm 0.29$ & $17.52 \pm 1.12$ \\
\hline & Weathered & $10.30 \pm 0.42$ & $41.62 \pm 1.94$ \\
\hline
\end{tabular}



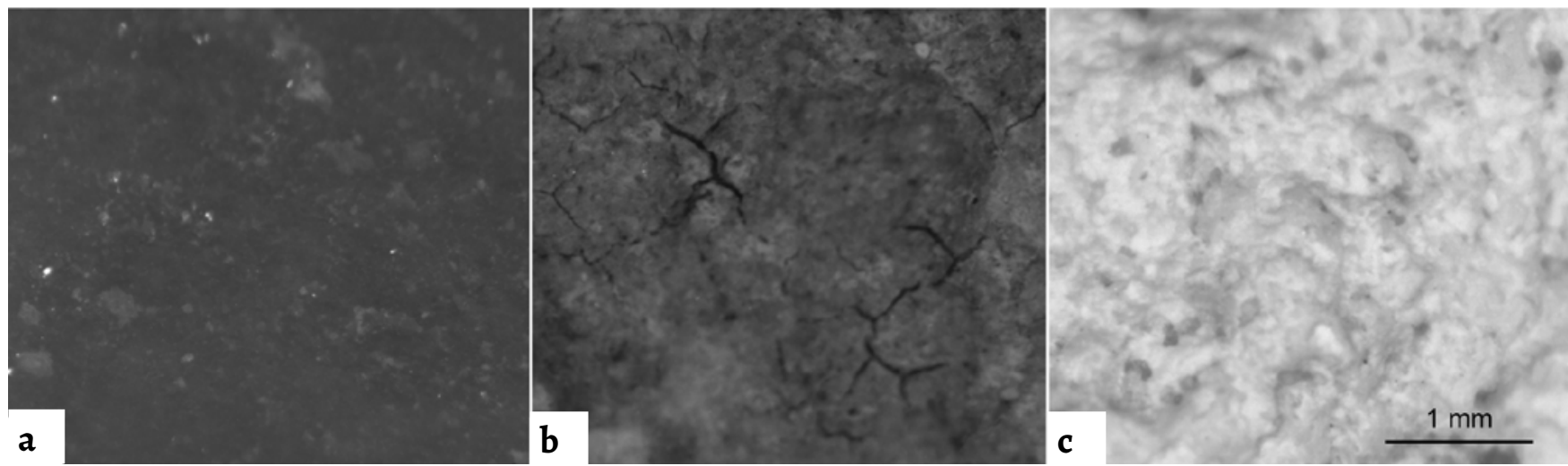

Figure 4. Micro-detailed images obtained by optical surface roughness (OSR) measurements: $a$ ) Even area of sample SXi8; $b$ ) External crust of the sample SX18; c) Coarse surface texture of sample SX19.

The micro-detailed surface images can be seen in Figure 4, and 3D OSR maps are presented in Figure 5.

By comparing the results obtained on the smooth, crystalline core zones and less weathered parts (that are more similar to fresh chert) of the two studied samples (SX18 and SX19), it can be seen that the Ra roughness values for sample SX19 are $43 \%$ higher than for sample SX18 (3.67 $\pm 0.29 \mu \mathrm{m}$ vs. $2.57 \pm 0.40 \mu \mathrm{m}$, respectively). The same occurs with the $\mathrm{Rz}$ values that are $87 \%$ higher in sample SX19 $(17.52 \pm 1.12 \mu \mathrm{m}$ vs. $9.35 \pm 1.37 \mu \mathrm{m})$. These results show that sample SX19 is much coarser than sample SX18 due to surface degradation processes, as was also observed in the macroscopic study. The average surface roughness values are greater in both the smoother and better-preserved areas and across the entire surface of sample SX19, which is denoted by the longer distances between the highest and deepest parts of the measurement areas indicated by the $\mathrm{Rz}$ parameter. In the coarse and decayed areas, the rough and dusty external zone of sample SX19 and the external crust of SX18 (crust 1, which according to XRD comprises quartz and calcite), roughness values are similar in the two samples, although slightly higher in sample SX19 $(7.43 \pm 0.34 \mu \mathrm{m}$ vs. $10.30 \pm 0.42 \mu \mathrm{m}$ in the Ra parameter and $40.82 \pm 1.84 \mu \mathrm{m}$ vs. $41.62 \pm 1.94 \mu \mathrm{m}$ in the Rz parameter respectively).

The micro-detailed images obtained with the profilometer (Figure 4) and the surface roughness 3D height maps
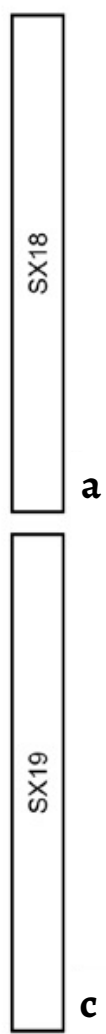
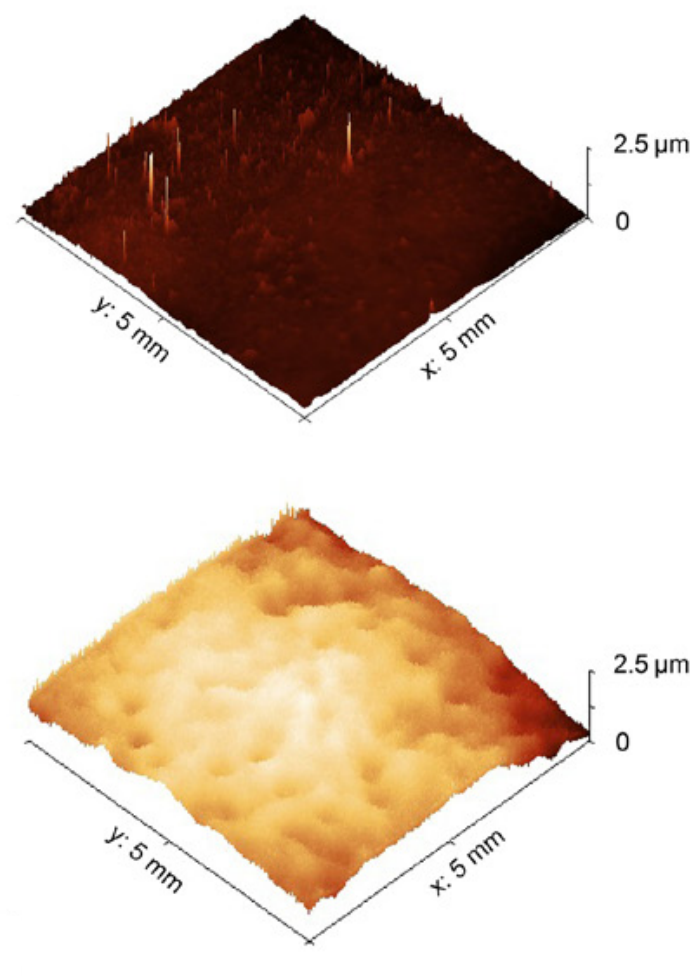
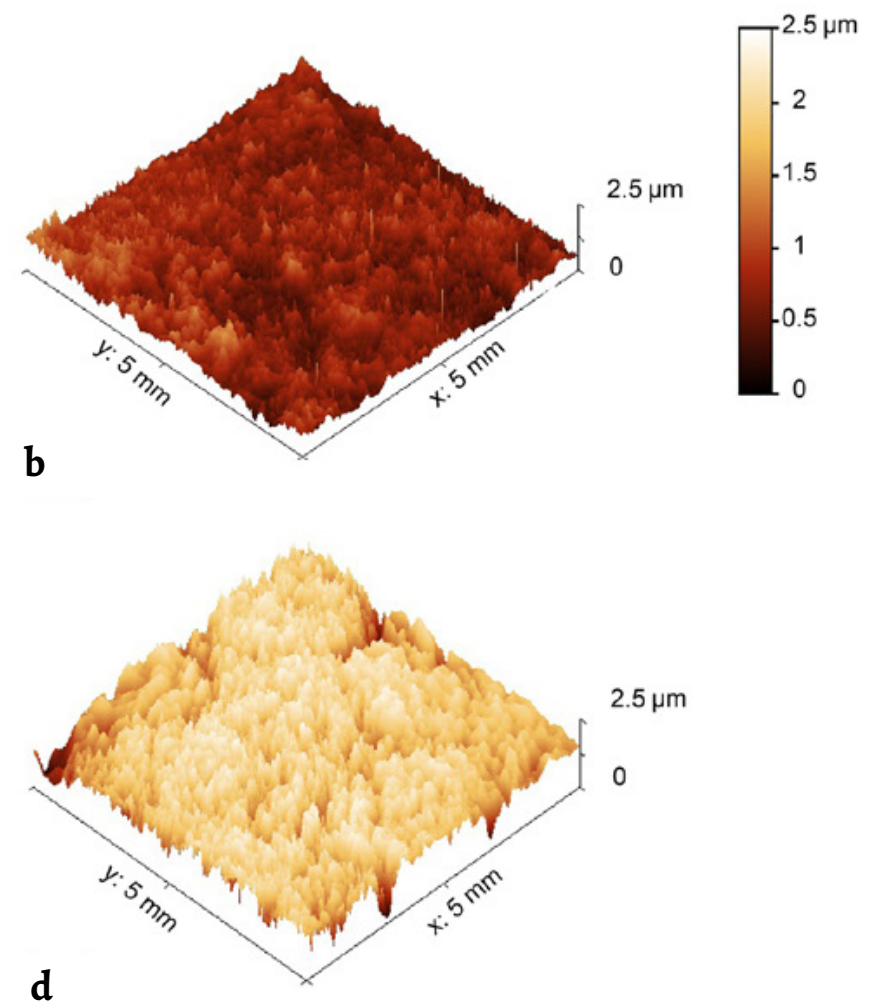

Figure 5. Surface roughness 3D height maps obtained under optical surface roughness (OSR) on the different surface areas of chert SX18 and SX19 samples: a) Even area of sample SX18; b) External crust of the sample SX18; c) Even area of sample SX19; $d$ ) Coarse surface of sample SX19. 
(Figure 5) show the surface differences on the texture morphology, and hence the surface roughness contrast among several zones of both samples. The image of an even area of sample SX18 shows a smooth, compacted and homogeneous surface (Figure $4 a$ and Figure 5a), whereas the image of sample SX19 reveals a whiter color and dustier, poorly-compacted surface, where mineral grains are clearly observed, as well as discontinuous areas with pores (Figure $4 c$ and Figure $5 c-d$ ). In the most decayed areas, some further differences can be seen (Figure $5 b-d$ ). The transition from the smooth area towards the external rough zone of sample SX19 can be observed as a progressive loss of homogeneity and compaction of the surface, showing up as a more white and porous, disaggregated grainy zone where loss of material is observed. In sample SX18, the image shows the previous step in the total decay process observed in sample SX19. The color is still darker than the surface coloring of sample SX19, although white areas not detected in the smooth zone can be observed. The surface of SX18 sample maintains its continuity and homogeneity, but cracks and fissures appear and, eventually, if decay processes continue, there could be loss of material and disaggregation of the surface, in a similar way to that observed in sample SX19.

\section{Environmental SEM-EDS}

Sample SX3 from the archaeological site exhibits silica with radial-fibrous textures in some areas and nodular textures in others (Figure 6). Even though sample $\mathrm{SX}_{17}$ is more homogenous, the fibrous texture is less rigidly oriented (Figure 6d).

The external part of sample SX18, from the outcrop, shows signs of dissolution, retraction cracks and has a higher calcium content (Figure 7a). A different zone (corresponding to the whitish crust) displays a similar texture to the crystalline core zone. However, in this case it is weathered due to dissolution-recrystallization processes (Figure $7 b$ ). In the crystalline core zone, a crypto-crystalline, fairly fibrous texture can be seen (Figure $7 c$ ), together with some areas containing pores and fissures from 50 to $100 \mu \mathrm{m}$ in size, almost completely cemented by micro-crystalline quartz crystals (Figure $7 d$ ). These pore and fissured areas might correspond to moganite, leading to a certain degree of micro-porosity.

These results are in line with those obtained by XRD, where differences between the two crusts were distinguished (the outer crust had a higher degree of alteration and comprised quartz and calcite, while the other crust was composed of calcite and moganite). Variability in moganite content has been linked to macroscopic color and texture variations within a sample, indicating that variable moganite content may be linked to changing environmental or depositional conditions [42]. The outer zone of sample SX19 presents crystals with radial-fibrous morphologies (which could be moganite) together with nodules of agglomerated
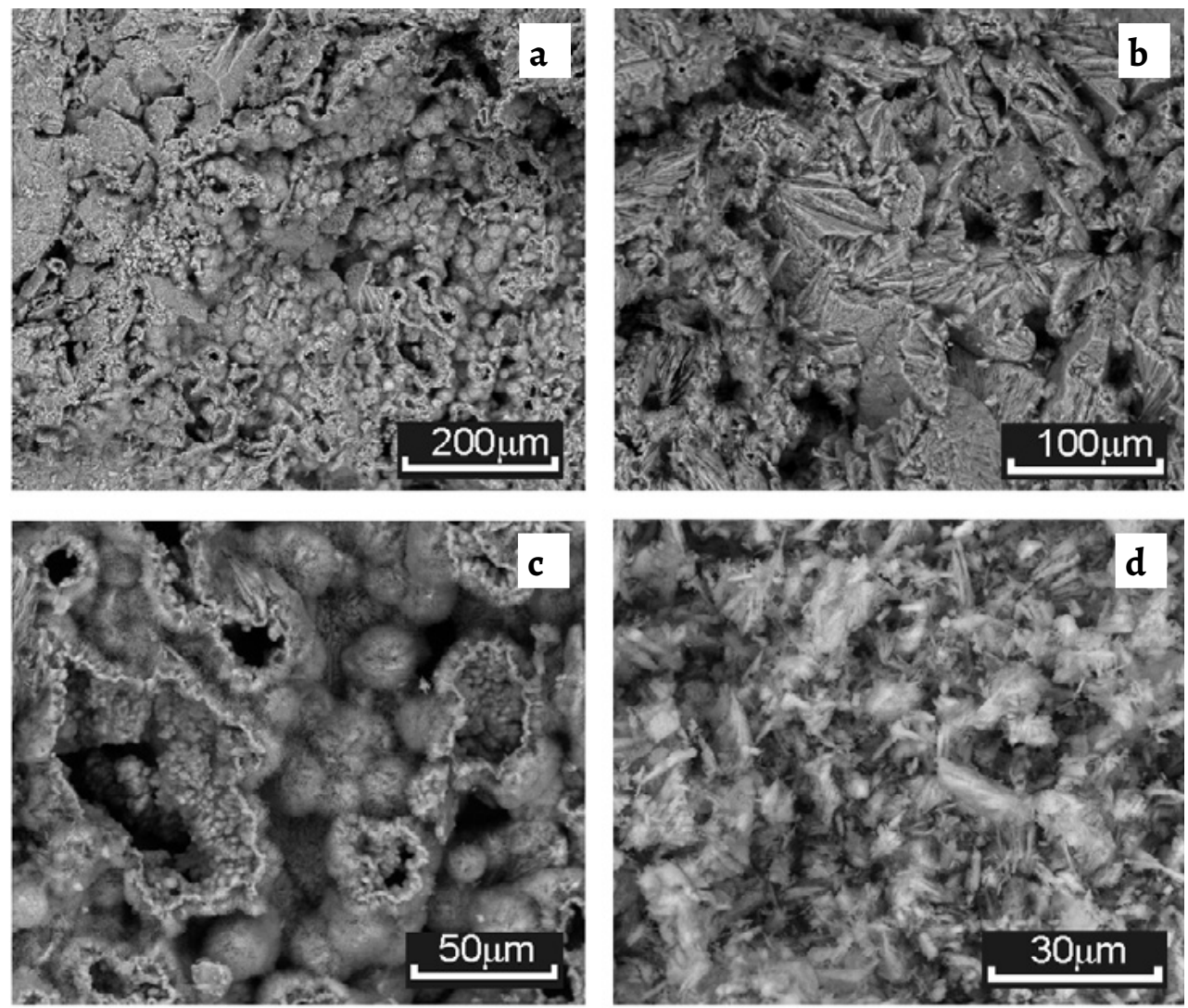

Figure 6. Environmental SEM (ESEM) images from the archaeological site chert samples: $a$ ) Sample SX3; $b$ ) Detail of radial-fibrous texture area in former sample; c) Detail of nodular textures in the same sample; $d$ ) Detail of disoriented fibrous texture in sample SX17. 

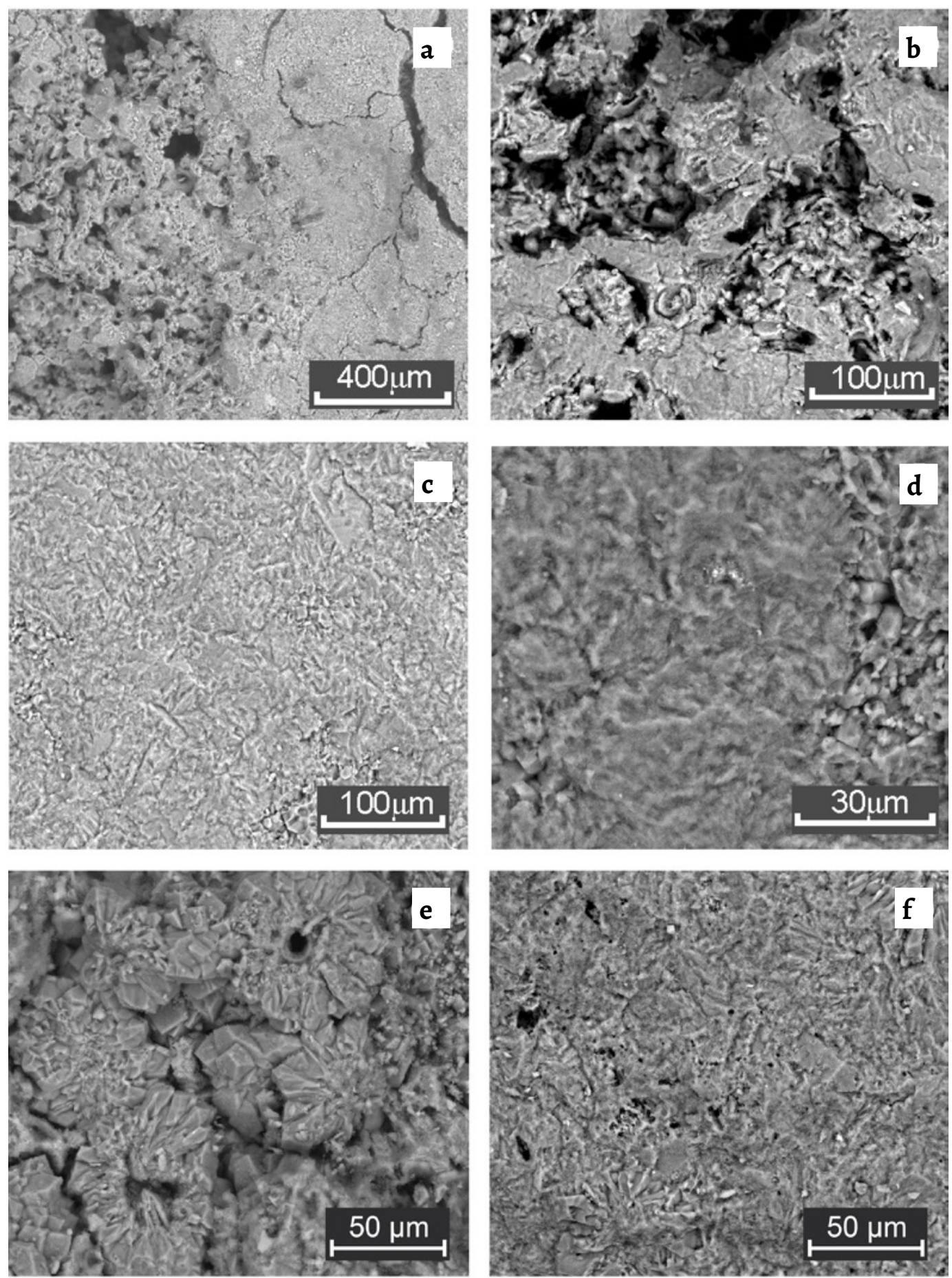

Figure 7. ESEM images from chert outcrop samples: $a$ ) external porous zone of sample SX18 with signs of dissolution processes and retraction cracks; b) crystalline core zone of sample SX18 weathered due to dissolution-recrystallization processes; $c$ ) crystalline core zone of sample SX18 with a cryptocrystalline quite fibrous texture; $d$ ) pores and fissures completely cemented by micro-crystalline quartz crystals in sample SX18; $e$ ) crystals with radialfibrous morphologies in external zones of sample SX19; f) inner zone of sample SX19 with less abundant radial-fibrous crystals.

dodecahedral crystals with inter-crystalline porosity (Figure 7e). The inner zone of this sample displays less abundant radial-fibrous crystals. However, there are signs of corrosion pits which give rise to porosity in the cryptocrystalline quartz matrix (Figure $7 f$ ). These corrosion signs might be the cause of the higher roughness values obtained in the inner zone of this sample compared to the values measured on the crystalline core zone of sample SX18.

\section{Study of consolidation treatments Environmental SEM-EDS}

Figure 8 shows some representative ESEM images of the samples before and one month after the application of the consolidating products. The surface morphology is altered in all cases due to the application of the products. In the samples treated with $\mathrm{SiO}_{2}$ nanoparticles (e.g., sample $\mathrm{SX}_{3}$ ), the product is heterogeneously distributed (Figure $8 c-d$ ) 


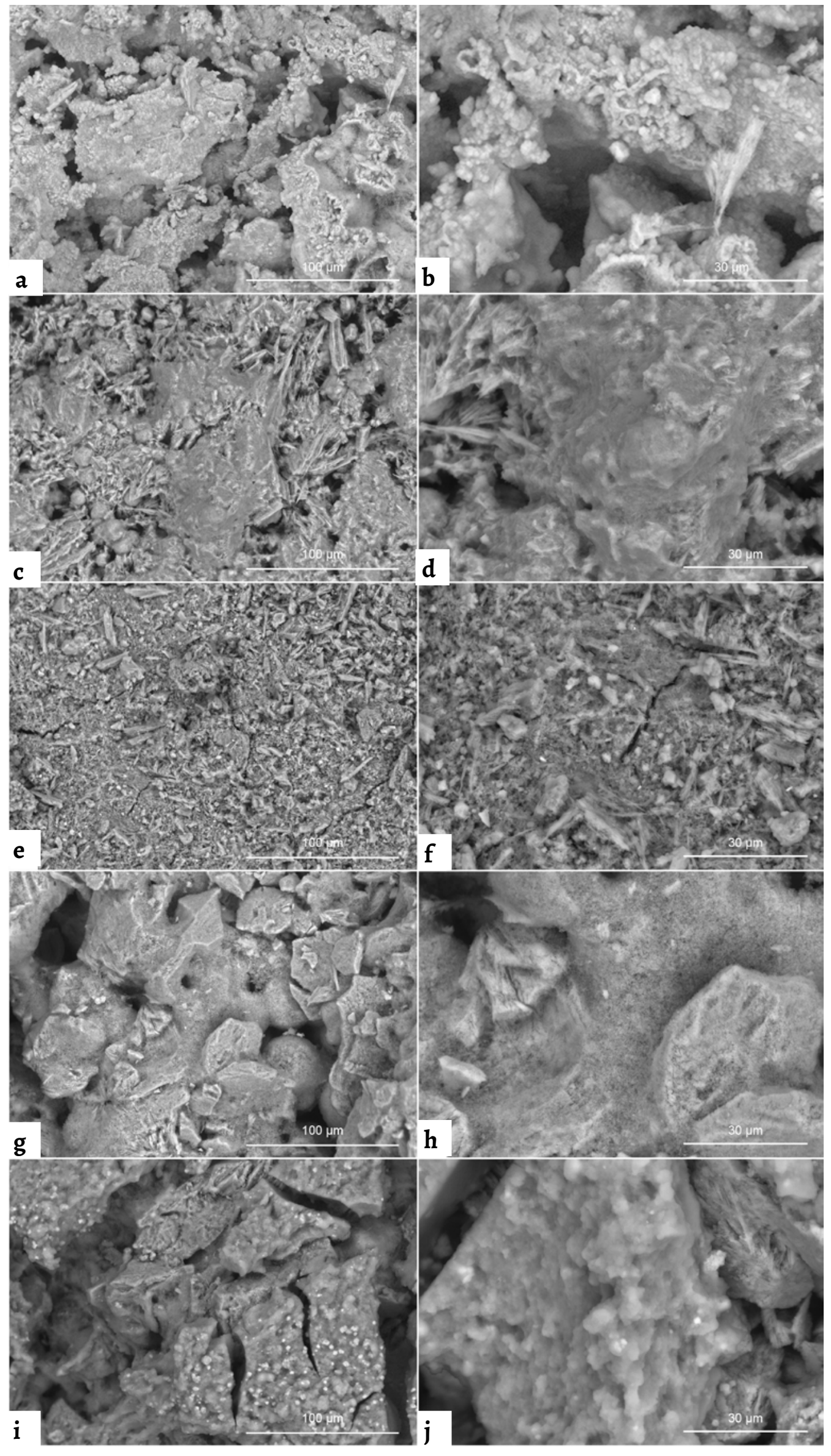

Figure 8. ESEM images with $800 x$ and $3000 x$ magnifications of control sample and the samples one month after the application of the consolidating products: $a, b$ ) Control sample $\mathrm{SX}_{3} ; c, d$ ) Sample $\mathrm{SX}_{1}$ treated with $\mathrm{SiO}_{2}$ nanoparticles; $\left.e, f\right)$ Sample SX6 treated with ethyl silicate; $g$, $h$ ) Sample SX9 treated with acrylic resin; $i, j)$ Sample SX11 treated with the nanoparticle $\mathrm{SiO}_{2}$ and $\mathrm{Ca}(\mathrm{OH})_{2}$ mixture. 
giving rise to agglomerations in the less porous and more crystalline areas of the sample. In addition, a dense gel layer with a texture apparently smooth can be observed surrounding and covering the quartz crystals. This morphology is similar to that observed in previous research works where the same product was applied to sandstone samples [23]. However, in this case, cracks are not observed in the consolidating product due to the formation of fewer surface agglomerations. In the samples consolidated with ethyl silicate (e.g., sample SX6) a fractured coating can be seen across the entire surface (Figure $8 e-f$ ). Despite both products produce silica gel, the morphology of this gel is very different. The samples consolidated with acrylic resin (e.g., SX9) show a surface covered by a smooth, dense coating that also covers the small pores (Figure $8 g-h$ ). The product is also accumulated in the inter-granular areas. By comparison of this coating with that produced by $\mathrm{SiO}_{2}$ nanoparticles, in this case the outer layer is smooth and continuous whereas the nanoparticles generate micro-roughness surfaces.

Figure $8 i$ and $8 j$ show the surface of sample SX11 after the application of the mixture of $\mathrm{SiO}_{2}$ and $\mathrm{Ca}(\mathrm{OH})_{2}$ nanoparticles. A totally fractured, dense, thick coating has been generated on the surface. In the detailed image (Figure 8j) it can be seen that this dense coating is formed by $\mathrm{Ca}(\mathrm{OH})_{2}$ nanoparticles embedded in the silica gel. The morphology of these nanoparticles is similar to those observed in previous research works [25], but in this case the agglomeration is produced inside the amorphous silica gel, giving rise to an increased roughness surface.

\section{Peeling test}

The results of this type of adhesion test performed one month after the application of the products are compiled in Table 5. In all the samples a reduction of released material was produced after the application of the products due to the consolidating effect that increases the surface cohesion. The greatest reduction was produced in the samples treated with ethyl silicate, where the released material was $95 \%$ less (54 mg of released material in the control samples decreased to $3 \mathrm{mg}$ in the consolidated samples). The $\mathrm{SiO}_{2}$ nanoparticle product was the next most effective product, since the released material was reduced by $89 \%$ (6 mg of material being released). The acrylic resin product and the mixture of nanoparticles resulted in a much lower reduction (54\% and
Table 5. Average of released material (mg) obtained by peeling test on control and treated chert samples after one month of the consolidating product application and decrease of release material (\%) regarding the control sample.

\begin{tabular}{|c|c|c|c|c|c|c|}
\hline & & \multicolumn{5}{|c|}{ Released material (mg) } \\
\hline & & $\begin{array}{l}\text { Control } \\
\text { sample }\end{array}$ & $\begin{array}{l}\text { Nano } \\
\mathrm{SiO}_{2}\end{array}$ & $\begin{array}{l}\text { Ethyl } \\
\text { silicate }\end{array}$ & $\begin{array}{l}\text { Acrylic } \\
\text { resin }\end{array}$ & $\begin{array}{l}\text { Nano } \\
\text { Mixture }\end{array}$ \\
\hline \multirow[t]{10}{*}{ Test sequence } & 1 & 11.40 & 0.73 & 0.50 & 6.00 & 5.20 \\
\hline & 2 & 9.10 & 0.70 & 0.30 & 4.13 & 4.87 \\
\hline & 3 & 6.70 & 0.23 & 0.30 & 3.37 & 4.77 \\
\hline & 4 & 6.15 & 1.27 & 0.40 & 2.03 & 3.13 \\
\hline & 5 & 4.85 & 1.27 & 0.17 & 1.70 & 3.03 \\
\hline & 6 & 4.20 & 0.27 & 0.23 & 1.80 & 2.30 \\
\hline & 7 & 2.80 & 0.33 & 0.23 & 1.53 & 2.17 \\
\hline & 8 & 3.60 & 0.37 & 0.07 & 1.17 & 1.63 \\
\hline & 9 & 2.15 & 0.90 & 0.13 & 1.70 & 2.07 \\
\hline & 10 & 3.50 & 0.13 & 0.20 & 1.43 & 2.93 \\
\hline \multicolumn{2}{|l|}{$\begin{array}{l}\text { Released } \\
\text { material (mg) }\end{array}$} & 54 & 6 & 3 & 25 & 32 \\
\hline \multicolumn{2}{|c|}{$\begin{array}{l}\text { Decrease of released } \\
\text { material (\%) }\end{array}$} & $\mathrm{n} / \mathrm{a}$ & 89 & 95 & 54 & 41 \\
\hline
\end{tabular}

$41 \%$, respectively). By mixing both types of nanoparticles, the consolidation effectiveness of the $\mathrm{SiO}_{2}$ nanoparticles seems to be limited since alone its reduction of released material is much higher ( $89 \%$ ) than when it is mixed. In all cases, the material released in the tenth sequence was less than the amount released in the control samples $(3.5 \mathrm{mg})$, i.e. with ethyl silicate it was $0.2 \mathrm{mg}$, and with $\mathrm{SiO}_{2}$ nanoparticles it was $0.13 \mathrm{mg}$, since a greater reduction is produced by the higher surface cohesion.

\section{Spectrophotometry}

The average values of chromatic changes on the surface of the samples one month after applying the consolidating products are compiled in Table 6 . These changes can be divided into two groups: i) those generated by the nanoparticles, which produced similar results although there were greater variations in the case of the nanoparticle mixture, and ii) changes produced by the ethyl silicate and the acrylic resin (being greater in this latter product). The milky-white color of the samples made some changes easily visible to the naked eye, more than on any other color.

Table 6. Average variations $(\Delta)$ promoted on chromatic parameters ( $L^{*}$, lightness; $\mathrm{a}^{*}$ position between red and green; $\mathrm{b}^{*}$ position between yellow and blue; $\mathrm{C}^{*}$, Chroma; $\mathrm{E}^{*}$, total color; YI, yellow index; WI, white index and brightness) on the chert samples after one month of the consolidating products application.

\begin{tabular}{|c|c|c|c|c|c|c|c|c|}
\hline $\begin{array}{l}\text { Consolidating } \\
\text { product }\end{array}$ & $\Delta \mathbf{L}^{*}$ & $\Delta \mathbf{a}^{*}$ & $\Delta \mathbf{b}^{*}$ & $\Delta \mathbf{C}^{*}$ & $\Delta \mathbf{E}^{*}$ & $\begin{array}{l}\text { YI } \\
\left(E_{313-73)}\right.\end{array}$ & $\begin{array}{l}\text { WI } \\
\text { (E313-73) }\end{array}$ & Brightness (ISO) \\
\hline $\mathrm{Nano} \mathrm{SiO}_{2}$ & $-5.74 \pm 2.99$ & $-0.74 \pm 0.49$ & $-2.73 \pm 1.12$ & $-2.88 \pm 1.19$ & $6.15 \pm 3.30$ & $-3.59 \pm 1.51$ & $-4.24 \pm 1.09$ & $-9.04 \pm 4.25$ \\
\hline Ethyl silicate & $-6.16 \pm 2.16$ & $1.15 \pm 0.76$ & $3.67 \pm 2$ & $3.86 \pm 1.3$ & $7.43 \pm 3.73$ & $2.98 \pm 0.39$ & $-17.30 \pm 10$ & $-13 \pm 11$ \\
\hline Acrylic resin & $-11.60 \pm 1.5$ & $2.61 \pm 0.04$ & $5.95 \pm 2.99$ & $6.51 \pm 2.7$ & $13.75 \pm 2.9$ & $11.95 \pm 4.6$ & $-16.1 \pm 3.45$ & $-17.63 \pm 1$ \\
\hline Nano Mixture & $-14.22 \pm 2.1$ & $0.04 \pm 0.19$ & $-1.21 \pm 0.77$ & $-1.17 \pm 0.79$ & $14.28 \pm 2.16$ & $-1.21 \pm 0.14$ & $-14.02 \pm 3$ & $-24.20 \pm 4.1$ \\
\hline
\end{tabular}




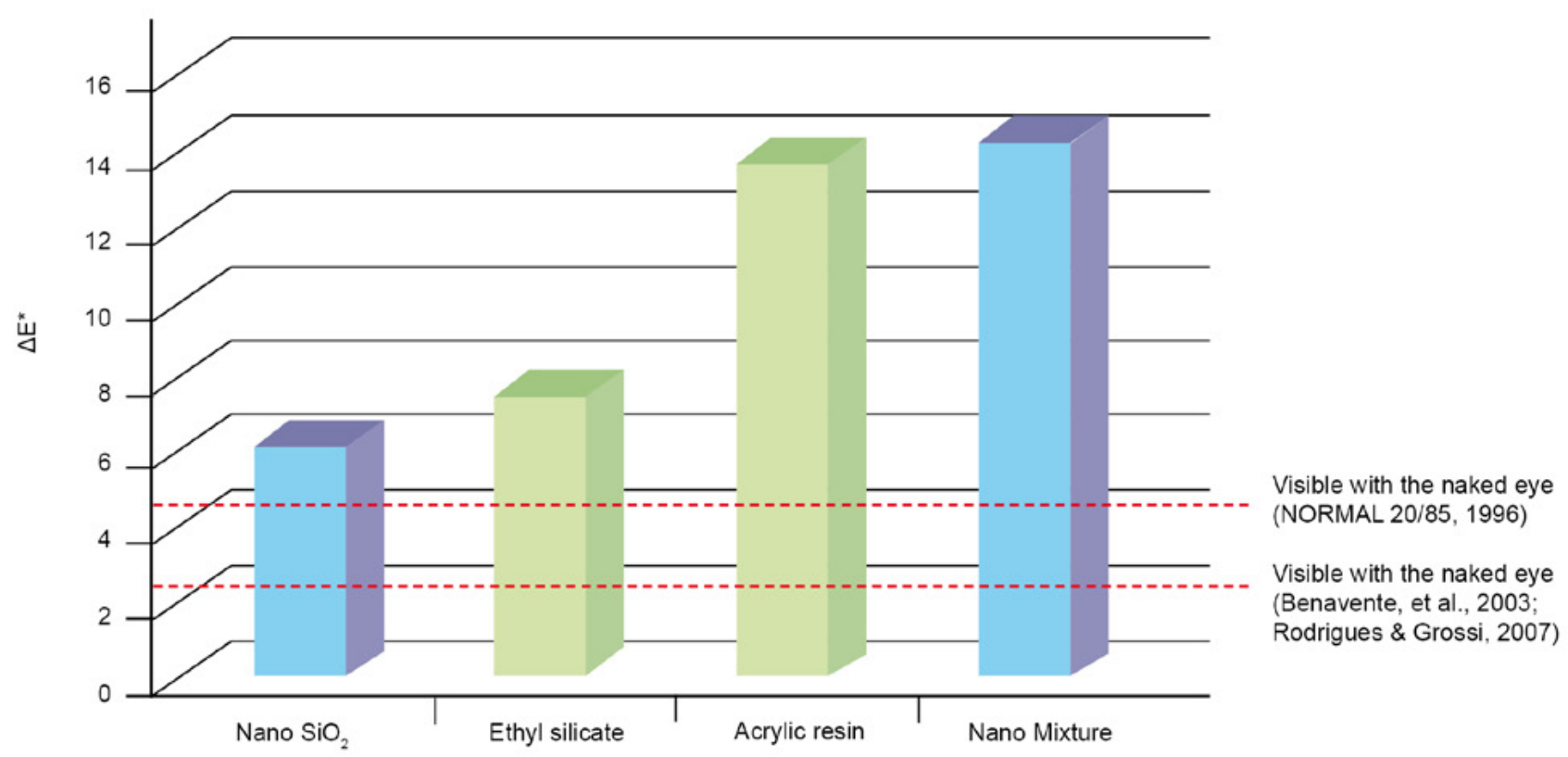

Figure 9. Total color difference $\left(\Delta \mathrm{E}^{*}\right)$ values of chert samples before and after one month of the application of consolidating products.

The product that generates the least chromatic changes is that based on $\mathrm{SiO}_{2}$ nanoparticles. However, the total color difference $\left(\Delta E^{*}\right)$ caused by this product before and after its application is very high $(6.15 \pm 3.30)$. This means that the changes produced by this product are visible with the naked eye, since $\Delta E^{*}$ is higher than 5 [43] or above 3 according to other authors [44] (Figure 9). Changes in other chromatic parameters included a reduction in the lightness values $(-5.74 \pm 2.99)$. The $b^{*}$ parameter decrease $(-2.73 \pm 1.12)$ means that the sample develops a bluish tone. In previous work on $\mathrm{SiO}_{2}$ characterization [23] a certain bluish coloring of the silica gel was also observed, even though this product was originally transparent. This bluish tonality is also the cause of the reduction in the Chroma parameter $\left(\mathrm{C}^{*}\right)(-2.88 \pm 1.19)$, making the original color of the sample (white) look less pure and more mixed, as well as the reduction in the yellow index (YI) $(-3.59 \pm 1.51)$ due to the tone change towards blue. Additionally, there is also a reduction in the white index (WI) values $(-4.24 \pm 1.09)$ losing the white tonality and decreasing the brightness value $(-9.04 \pm 4.25)$.

The nanoparticle mixture produces similar changes but becomes a little more pink. $\Delta \mathrm{E}^{*}$ is much higher $(14.28 \pm 2.16)$ and there is a greater decrease in the lightness and brightness parameters (-14.22 \pm 2.1 and $-24.20 \pm 4.1$, respectively). This yields the highest changes of all the products tested and makes this consolidating product inappropriate for being used (Figure 9). The changes produced by the ethyl silicate and acrylic resin are different regarding the tonality acquired by the surface of the samples after application. In both cases $\Delta \mathrm{E}^{*}$ is too high, this change is detectable with the naked eye $(7.43 \pm 3.73$ for the ethyl silicate and $13.75 \pm 2.9$ for the acrylic resin). The lightness value also decreases to a greater extent than in the case of $\mathrm{SiO}_{2}$ nanoparticles $(-6.16 \pm 2.16$ for ethyl silicate and $-11.60 \pm 1.5$ for acrylic resin). In both cases, and contrary to what happens with nanoparticles, the Chroma $\left(C^{*}\right)$ values increase due to the color change produced on the surface (3.86 \pm 1.3 for ethyl silicate and $6.51 \pm 2.7$ for acrylic resin). The $b^{*}$ parameter also increases, with a surface tone change to yellow (typical of this type of consolidating product), giving rise to values of $9.13 \pm 1$ in the case of ethyl silicate and $5.95 \pm 2.99$ in the acrylic resin. Similar changes to the YI values are also seen; in this case the values increase due to the yellow coloring (3.67 \pm 2 for ethyl silicate and $5.95 \pm 2.99$ for acrylic resin). The WI values decrease due to the loss of white tonality (the original color of the surface) to a greater extent compared to the $\mathrm{SiO}_{2}$ nanoparticles (-17.30 \pm 3 for ethyl silicate and $-14.02 \pm 3$ for acrylic resin). Therefore, is important to note that although both products $\left(\mathrm{SiO}_{2}\right.$ nanoparticles and ethyl silicate) generate a silica gel in the treated samples, chromatically they behave very differently. The behavior of the $\mathrm{SiO}_{2}$ nanoparticles is closer to that observed for the $\mathrm{Ca}(\mathrm{OH})_{2}$ nanoparticles, whereas the result obtained with the ethyl silicate is closer to that of the acrylic resin.

\section{Conclusions}

The state of conservation of the chert samples does not depend on the environment or burial conditions related to salt crystallization processes, since the natural decay of fresh chert samples is produced regardless of the archeological site where the chert remains were found. In the sites, the soils where the samples were buried did not contain soluble salts. Besides, similar degradation is seen in fresh chert samples from the surrounding outcrops. However, moisture and water percolation through the site where the samples were collected could have accelerated degradation 
processes causing further decay. The key point in chert decay seems to be moganite mineral content. Samples that contain only quartz are not significantly altered (and therefore need less preservation treatment); samples with moganite (more soluble and microporous) and quartz are more weathered and powdery (requiring consolidation treatments, particularly on their surfaces), whereas samples with quartz and calcite are the most detached and worst preserved (requiring both internal and surface consolidation treatments). The original moganite content of this latter group of samples could have been much higher, giving rise to the increased porosity and favoring the penetration of carbonate-rich water allowing calcite to precipitate within the pores. However, part of the calcite identified in the archaeological remains might come from the limestone outcrops where the chert was originally extracted.

The four consolidating products tested had positive and negative aspects that are reflected in the modifications caused in the physical (surface morphology and cohesion) and aesthetic properties of the samples. One product may be more adequate than another depending on the characteristics of the treated sample and the modifications that the product produces in the sample, including: i) composition of the substrate (which in this case is likely to determine conservation state); ii) chemical or physical compatibility between applied product and substrate; iii) superficial or internal damage, which determines conservation needs; iv) environmental conditions; v) need for later treatments, especially water-based; vi) future of the treated object (exhibition, storage, conservation on site) among others.

The mixture of $\mathrm{SiO}_{2}$ and $\mathrm{Ca}(\mathrm{OH})_{2}$ nanoparticles shows positive results with regard to surface cohesion, thicker morphology and resulting in a denser final product. However, the significant chromatic changes and shrinkage of the generated outer layer on drying make it unsuitable for being use as a consolidating product for archaeological samples. However, it could be a promising product for the volumetric reintegration of lost areas or for filling cracks and fissures in siliceous and calcareous substrates.

Acrylic resin Paraloid B72 (one of the most frequentlyused consolidating products applied in the field of archaeological conservation) has a very low consolidating effect and very significant chromatic changes compared to the other products. This resin is not water soluble and when it is mixed with common solvents such as acetone a white thin film is developed on the surface. For this reason, even though it is the fastest-working product it is not suitable to be used under moisture conditions. The consolidation speed is a very important issue to consider as the manipulation of the samples (extraction, storage...) accelerate the deterioration process. The application of these treatments demands space and time that is not usually available. In addition, when such a treatment is applied, it is because the object is in very bad conditions. Thus, it is necessary to apply subsequent treatments that also require time.
The ethyl silicate product Tegovakon V100 shows a very effective consolidating action. However, it produces significant chromatic changes and develops a superficial film, occluding porosity and remaining temporally hydrophobic. Hence, this product will influence the performance of subsequent water-based treatments. Furthermore, the coating generated on the surface displays cracks and fractures partially due to the high humid consolidation environment that can commonly occur in archaeological sites.

Finally, the $\mathrm{SiO}_{2}$ nanoparticle product shows an effective short-term consolidating action, with a gel generation of 3-4 days, being produced faster than in the case of ethyl silicate. The chromatic changes (although visually perceptible) are less significant. It could be applied to substrates containing water, allowing the subsequent application of waterbased treatments including cleaning and volumetric reintegration. However, durability tests carried out on these materials using these products shows the longerterm effects and the importance of performing accelerating ageing tests before applying consolidating treatments to archaeological artifacts [17].

\section{Acknowledgements}

This research work was carried out at the Instituto de Geociencias (CSICUCM) and was founded by predoctoral fellowship JAE-PreDoc 2010-2014 (CSIC) and the Adaptability and Employment Programme of The European Social Fund (FSE 2007-2013). The characterization analyses and tests were funded by Rafael Fort under Geomaterials Programme (S2009/MAT1629). Research of López-Polín is founded by MINECO-FEDER Project "Comportamiento ecosocial de los homínidos de la Sierra de Atapuerca durante el Cuaternario IV" (CGL2015-65387-C3-1-P); SGR 1040 (AGAUR); 2016PFR-URV-B2-17.

The authors are grateful for the XRD analyses of total powder samples performed by Ivan Serrano from the Petrology and Geochemistry department of Faculty of Geology (UCM) and the micro-diffraction analyses performed by Julian Velázquez Cano from CAI-DRX of Faculty of Chemistry (UCM). Marta Furio from the Museo Nacional de Ciencias Naturales (CSIC) is also acknowledged for the ESEM-EDS analyses.

\section{REFERENCES}

1. Luedtke, B. E., An Archeologist's guide to Chert and Flint, Archaeological Research Tools, Institute of Archaeology, University of California, Los Angeles (1992).

2. Aguirre, E., 'Atapuerca (Burgos, Northern Spain) - Potential, progress and questions', CFS Courier Forschungsinstitut Senckenberg 259 (2007) 111-120.

3. Ortega, A. I.; Benito-Calvo, A.; Pérez-González, A.; Carbonell, E.; Bermúdez de Castro, J. M.; Arsuaga, J., 'Atapuerca Karst and its Palaeoanthropological Sites',in Landscapes and landforms of Spain, eds. F. Gutiérrez and M. Gutiérrez, Springer, Netherlands (2014) 101-111.

4. Carbonell, E.; Esteban, M.; Nájera, A. M. N.; Mosquera, M.; Rodríguez, X. P.; Ollé, A.; Ortega, A. I., 'The Pleistocene site of Gran Dolina, Sierra de Atapuerca, Spain: a history of the archaeological investigations', Journal of Human Evolution 37 (3-4) (1999) 313-324, https://doi.org/10.1006/jhev.1999.0282. 
5. Rodríguez, J.; Burjachs, F.; Cuenca-Bescós, G.; García, N.; Van der Made, J.; Pérez González, A.; Carbonell, E.,'One million years of cultural evolution in a stable environment at Atapuerca (Burgos, Spain)', Quaternary Science Reviews 30 (11-12) (2011) 1396-1412, https://doi.org/10.1016/j. quascirev.2010.02.021.

6. Mosquera, M.; Ollé, A.; Pérez, A.; Rodríguez, X. P.; Vaquero, M.; Vergés, J. M.; Carbonell, E., 'Valle de las Orquídeas: un yacimiento al aire libre del Pleistoceno Superior en la Sierra de Atapuerca (Burgos)', Trabajos de Prehistoria 64 (2007) 143-156.

7. Navazo, M.; Alonso-Alcalde, R.; Benito-Calvo, A.; Díez, J. C.; Pérez-González, A.; Carbonell, E., 'Hundidero: mis 4 open air neanderthal occupations in Sierra de Atapuerca', Archaeology, Ethnology and Anthropology of Eurasia 39(4) (2011) 29-41, https:// doi.org/10.1016/j.aeae.2012.02.004.

8. Ortega, A. I.; Juez, L.; Carretero, J. M.; Arsuaga, J.; PérezGonzález, A.; Ortega, M. C.; Martínez, I., 'The Portalón at Cueva Mayor', in The Early Neolithic in the Iberian Peninsula. Regional and Transregional Components, Proceedings of the XV World Congress, ed. M. Diniz, Archaeopress, Lisboa (2008) 3-9.

9. Vergès, J. M.; Allué, E.; Angelucci, D. E.; Burjachs, F.; Carrancho, A.; Cebrià, A.; Vaquero, M., 'Los niveles neolíticos de la cueva de El Mirador (Sierra de Atapuerca, Buegos) nuevos datos sobre la implantación y el desarrollo de la economía agropecuaria en la submeseta norte', in IV Congreso Del Neolítico Peninsular, eds. M. S. Hernández Pérez, J. A. Soler Diáz \& J. A. López Padilla, Museo Arqueológico de Alicante MARQ, Alicante (2008) 418-427.

10. Ollé, A.; Mosquera, M.; Rodríguez, X. P.; de LomberaHermida, A.; García-Antón, M. D.; García-Medrano, P.; Carbonell, E., 'The Early and Middle Pleistocene technological record from Sierra de Atapuerca (Burgos, Spain)', Quaternary International 295 (2013) 138-167, https://doi.org/10.1016/j. quaint.2011.11.009.

11. Schmalz, R. F., 'Flint and the Patination of Flint Artifacts', Procceding of the Prehistoric Society 26 (1960) 44-49.

12. Hurst, V. J.; Kelly, A. R., 'Patination of Cultural Flints: Flint artifacts can be dated by cortical changes in mineralogy and texture', Science 134 (1961) 251-256, https://doi.org/10.1126/ science.134.3474.251.

13. Burroni, D.; Donahue, R. E.; Pollard, A. M.; Mussi, M., 'The Surface Alteration Features of Flint Artefacts as a Record of Environmental Processes', Journal of Archaeological Science 29(11) (2002) 1277-1287, https://doi.org/10.1006/jasc.2001.0771.

14. López-Polín, L.; Gómez, G.; García-Antón, M. D.; Ibáñez, N.; Solé, A.; Guiu, J.; Carbonell, E., 'La restauración de restos óseos e industria lítica en los yacimientos pleistocenos de la Trinchera del Ferrocarril (Sierra de Atapuerca, Burgos)', Patina 15 (2008) 33-44.

15. Font, B.; López-Polín, L.; Ollé, A., 'Description and characterization of the natural alteration of chert artefacts from Atapuerca (Burgos, Spain), Cansaladeta (Tarragona, Spain) and Orgnac 3 (Ardèche, France)', Annali dell'Università di Ferrara Museologia Scientifica e Naturalistica 6 (2010) 103-110.

16. García-Antón, M. D.; Morant, N.; Mallol, C., 'L'approvisionnement en matières premières lithiques au Pléistocène inférieur et moyen dans la Sierra de Atapuerca, Burgos (Espagne)', L'Anthropologie 106(1) (2002) 41-55, https:// doi.org/10.1016/S0003-5521(02)01086-5.
17. Navazo, M.; Colina, A.; Domínguez-Bella, S.; Benito-Calvo, A., 'Raw stone material supply for Upper Pleistocene settlements in Sierra de Atapuerca (Burgos, Spain): flint characterization using petrographic and geochemical techniques', Journal of Archaeological Science 35(7) (2008) 1961-1973, https://doi. org/10.1016/j.jas.2007.12.009.

18. Falguères, C.; Bahain, J.-J.; Bischoff, J. L.; Pérez-González, A.; Ortega, A. I.; Ollé, A.; Arsuaga, J. L., 'Combined ESR/U-series chronology of Acheulian hominid-bearing layers at Trinchera Galería site, Atapuerca, Spain', Journal of Human Evolution 65(2) (2013) 168-184, https://doi.org/10.1016/j.jhevol.2013.05.005.

19. García-Medrano, P.; Cáceres, I.; Ollé, A.; Carbonell, E., 'The occupational pattern of the Galería site (Atapuerca, Spain): A technological perspective', Quaternary International 433 (2017) 363-378, https://doi.org/10.1016/j.quaint.2015.11.013.

20. Berger, G. W.; Pérez-González, A.; Carbonell, E.; Arsuaga, J. L.; Bermúdez de Castro, J. M.; Ku, T. L., 'Luminescence chronology of cave sediments at the Atapuerca paleoanthropological site, Spain', Journal of Human Evolution 55(2) (2008) 300-311, https://doi.org/10.1016/j. jhevol.2008.02.012.

21. Zornoza-Indart, A.; López-Arce, P.; López-Polín, L., 'Durability of traditional and new nanoparticle based consolidating products for the treatment of archaeological stone tools: Chert artifacts from Atapuerca sites (Burgos, Spain)', Journal of Cultural Heritage 24 (2017) 9-21, https://doi.org/10.1016/j. culher.2016.10.019.

22. Wheeler, G., Alkoxysilanes and the Consolidation of Stone, Getty Conservation Institute, Los Angeles (2005).

23. Zornoza-Indart, A.; Lopez-Arce, P., 'Silica nanoparticles $\left(\mathrm{SiO}_{2}\right)$ : Influence of relative humidity in stone consolidation', Journal of Cultural Heritage 18 (2016) 258-270, https://doi.org/10.1016/j. culher.2015.06.002.

24. Ferreira, A. P.; Delgado, J., 'Stone consolidation: The role of treatment procedures', Journal of Cultural Heritage 9(1) (2008) 38-53, https://doi.org/10.1016/j.culher.2007.06.004.

25. Lopez-Arce, P.; Zornoza-Indart, A., 'Carbonation acceleration of calcium hydroxide nanoparticles: induced by yeast fermentation', Applied Physics A 120(4) (2015) 1475-1495, https:// doi.org/10.1007/s00339-015-9341-7.

26. Durnan, N., 'Limestone' in Stone Conservation: Principles and Practice, ed. A. Henry, Shaftesbury, Donhead (2006) 161-181.

27. Grissom, C. A.; Charola, A. E.; Boulton, A.; Mecklenburg, M. F., 'Evaluation over time of an ethyl silicate consolidant applied to ancient lime plaster', Studies in conservation 44(2) (1999) 113120, https://doi.org/10.1179/sic.1999.44.2.113.

28. Lazzarini, L.; Tabasso, M. L., Il restauro della pietra, CEDAM, Padova (1986).

29. De Witte, E.; Charola, A. E.; Sherryl, R. P., 'Preliminary tests on commercial stone consolidants' In Fifth International Congress on the Deterioration and Conservation of Stone, ed. G. Felix, V. Furlan, Presses Polytechniques Romandes, Lausanne (1985) 709-718.

30. Thorn, A., 'The Consolidation and Bonding of WaterSaturated Siliceous Stone With Lithium Silicate A Preliminary Evaluation', Paper presented at the CCI Symposium. Adhesives and Consolidants for Conservation: Research and Applications, Ottawa (2011).

31. Scherer, G. W.; Wheeler, G., 'Silicate Consolidants for 
Stone', Key Engineering Materials 391 (2009) 1-25, https://doi. org/10.4028/www.scientific.net/KEM.391.1.

32. Naidu, S.; Liu, C.; Scherer, G. W., 'Hydroxyapatite-based consolidant and the acceleration of hydrolysis of silicatebased consolidants', Journal of Cultural Heritage 16(1) (2015) 94101, https://doi.org/10.1016/j.culher.2014.01.001.

33. ISO. 4287. Geometrical product specifications (GPS)-surface texture: Profile method-terms, definitions and surface texture parameters 4287 Germany (1998).

34. Drdacky, M.; Lesak, J.; Rescic, S.; Slızkova, Z.; Tiano, P.; Valach, J., 'Standardization of peeling tests for assessing the cohesion and consolidation characteristics of historic stone surfaces', Materials and Structures 45 (2012) 505-520, https://doi. org/10.1617/s11527-011-9778-x.

35. ASTM. E313-73. Practice for calculating yellowness and whiteness indices from instrumentally measured color coordinates E313-73 (1993), Conshohocken, PA.: ASTM International.

36. ISO. 2470-2. Paper, board and pulps-Measurement of diffuse blue reflectance factor (ISO brightness) 2470-2. Geneva, Switzerland (1999).

37. Sala, R., Introducció d'un model reòlogic de les deformacions microscòpiques per ús en objectes lítics. Primers resultats al Complex del Plistocè Mig de la Sierra de Atapuerca, Universitat de Barcelona, Barcelona (1993).

38. Bustillo, M. A., 'Aparicion y significado de la moganita en las rocas de la silice: Una revisión', Journal of Iberian Geology $\mathbf{2 8}$ (2002) 157-166.

39. García-Guinea, J.; Bustillo, M. A.; Crespo, E.; Finch, A; Townsend, P. D.; Hole, D. E.; Correcher, V., 'Spectrallyresolved luminescence of moganite from Mogan (Gran Canaria)', in Conference on Micro-Raman Spectroscopy and Luminescence Studies in the Earth and Planetary Sciences, Mainz, Germany (2009).
40. Rodgers, K. A.; Cressey, G., 'The occurrence, detection and significance of moganite among some silica sinters', Mineralogical Magazine 65 (2001) 157-167, https://doi. org/10.1180/002646101550181.

41. Heaney, P.; Post, J. E., 'The widespread distribution of a novel silica polymorph in microcrystalline quartz varieties', Science 255 (1992) 441-443, https://doi.org/10.1126/science.255.5043.441.

42. Kingma, K.J.; Hemley, R. J., 'Raman spectroscopic study of microcrystalline silica', American Mineralogist 79 (1994) 269-273.

43. CNR-ICR. NORMAL 20/85. Interventi conservativi: progettazione esecuzione e valutazione preventive (1996), Milan, Italy.

44. Benavente, D.; Martınez-Verdu, F.; Bernabeu, A.; Viqueira, V.; Fort, R.; García del Cura, M. A.; Ordoñez, S., 'Influence of surface roughness on color changes in building stones', Color Research \&Application 28(5) (2003) 343-351, https://doi. org/10.1002/col.10178.

45. Rodrigues, J. D.; Grossi, A., 'Indicators and ratings for the compatibility assessment of conservation actions', Journal of Cultural Heritage 8(1) (2007) 32-43, https://doi.org/10.1016/j. culher.2006.04.007.

\author{
RECEIVED: 2019.10 .8 \\ REVISED: 2020.4.1 \\ ACCEPTED: 2020.4.9 \\ ONLINE: 2020.6.29
}

\section{(c) (1) (3) $(9)$}

This work is licensed under the Creative Commons Attribution-NonCommercial-NoDerivatives 4.0 International License. To view a copy of this license, visit http://creativecommons.org/licenses/by-nc-nd/4.o/deed.en. 